\section{Buletin Peternakan Tropis}

Bulletin of Tropical Animal Science

Doi: https://doi.org/10.31186/bpt.2.2.103-111
Bul. Pet. Trop. 2(2): 103-111, 2021

e-ISSN: 2722-0788

p-ISSN: 2722-1733

\title{
Kualitas Fisik Telur Ayam Arab, Ayam Kampung dan Ayam Ketarras serta Akseptabilitas Telur Ayam Ketarras Setara Telur Ayam Kampung
}

(The Eggs Physical Quality of Arab Chicken, Kampung Chicken and Ketarras Chicken and the Acceptability of Ketarras Chicken Eggs Equivalent to Kampung Chicken Eggs)

Okta Marlya ${ }^{1}$, Kususiyah $^{1 *}$, dan Desia Kaharuddin ${ }^{1}$

${ }^{1}$ Jurusan Peternakan, Fakultas Pertanian, Universitas Bengkulu, JI W.R. Supratman, Kandang Limun, Bengkulu $38371 \mathrm{~A}$

*Penulis Korespondensi: (kususiyah@unib.ac.id)

Dikirim (received): 05 Oktober 2021; dinyatakan diterima (accepted): 28 Oktober 2021; terbit (published): 15 November2021. Artikel ini dipublikasi secara daring pada https://ejournal.unib.ac.id/index.php/buletin_pt/index

\section{ABSTRACT}

This study aimed to evaluate the egg physical quality of Arab chickens, Kampung chickens and Ketarras chickens and the acceptability of Ketarras chicken eggs. Physical quality test of eggs used 3 types of eggs, namely 20 Arab chicken eggs, 20 Kampung chicken eggs and 20 Ketarras chicken eggs. The acceptability test of Ketarras chicken eggs used 10 Arab chicken eggs, 10 Kampung chicken eggs and 10 Ketarras chicken eggs respectively. They were placed randomly on the egg tray and asked the respondent to rate it. The data obtained were tabulated and discussed descriptively. The results showed that the eggs of Arab chickens, Kampung chickens, and Ketarras chickens had egg weights of $39.82 \pm 2.34 \mathrm{~g}, 40.36 \pm 3.48 \mathrm{~g}$ and $43.29 \pm 3.18 \mathrm{~g}$, respectively. Egg index of those chicken (\%) $76.53 \pm 3.03,74.34 \pm 3.63$ and $77.63 \pm 6.37$, respectively, whereas egg shell color score was $1.25 \pm 0.04,1.80 \pm 0.42$ and $2.10 \pm 0.3$, respectively. In additon, Those chickens had egg shell thickness $(\mathrm{mm}) 0.34 \pm 0.01,0.33 \pm 0.02$ and $0.34 \pm 0.01$, yolk index $0.44 \pm 0.05,0.40 \pm 0,04$ and $0.46 \pm 0.03$, albumen index $0.05 \pm 0.02,0.07 \pm 0.03$, and $0.07 \pm 0.02$, yolk color score $7.60 \pm 0.60,8,90 \pm 2.02$ and $7.50 \pm 0.83$, HU $62.08 \pm 11.90,71.83 \pm 13.02$ and $74.82 \pm 7.08$, eggshell percentage (\%) 12.59, 11.35 and 13.09, yolk percentage (\%) $30.60,35.38$, and 27.64, albumen percentage (\%) 56.81, 53.27 and 59.28, respectively. The acceptability of Ketarras chicken eggs equivalent to Kampung chicken eggs was $86.21 \%$. It was concluded that the color of the Ketarras chicken egg shell was brownish white like the color of the Kampung chicken egg shell with an acceptability level equivalent to that of a Kampung chicken egg of $86.21 \%$. Egg weight, egg index, yolk index, HU, egg shell percentage and albumen in Ketarras chickens were higher than Arab chickens and Kampung chickens. Ketarras chicken egg shell thickness is the same as Arab chicken eggs with the same albumen index as Kampung chicken eggs. The color score and percentage of Ketarras chicken yolks were lower than those of Arab and Kampung chicken eggs. The conclusion of this study is that the eggshell color of Ketarras chicken eggs is brownish white like Kampung chicken eggs with an acceptability level of Ketarras chicken eggs equivalent to Kampung chicken eggs of $86.21 \%$. The color score and percentage of Ketarras chicken yolks were lower than those of Arab and Kampung chicken eggs.

Key words: Ketarras chicken, Kampung chicken, Arab chicken, egg physical quality, egg acceptability

\section{ABSTRAK}

Tujuan penelitian ini untuk mengevaluasi kualitas fisik telur ayam Arab, ayam Kampung dan ayam Ketarras serta akseptabilitas telur ayam Ketarras. Uji kualitas fisik telur menggunakan 3 jenis telur, yaitu 20 butir telur ayam Arab, 20 butir telur ayam Kampung dan 20 butir telur ayam Ketarras. Uji akseptabilitas telur ayam Ketarras menggunakan 10 butir telur ayam Arab, 10 butir telur ayam Kampung dan 10 butir telur ayam Ketarras yang diletakkan secara acak pada karpet telur. Responden diminta untuk menilainya. Data 
ditabulasi dan dibahas secara deskriptif. Hasil penelitian menunjukkan bahwa telur ayam Arab, telur ayam Kampung, dan telur ayam Ketarras berturut-turut mempunyai berat telur 39,82 $\pm 2,34 \mathrm{~g}, 40,36 \pm 3,48 \mathrm{~g}$ dan $43,29 \pm 3,18 \mathrm{~g}$, indeks telur (\%) $76,53 \pm 3,03,74,34 \pm 3,63$ dan $77,63 \pm 6,37$, skor warna kerabang telur $1,25 \pm 0,04,1,80 \pm 0,42$ dan $2,10 \pm 0,3$, tebal kerabang telur $(\mathrm{mm}) 0,34 \pm 0,01,0,33 \pm 0,02$ dan $0,34 \pm 0,01$, indeks yolk $0,44 \pm 0,05,0,40 \pm 0,04$ dan $0,46 \pm 0,03$, indeks albumen $0,05 \pm 0,02,0,07 \pm 0,03$, dan $0,07 \pm 0,02$, skor warna

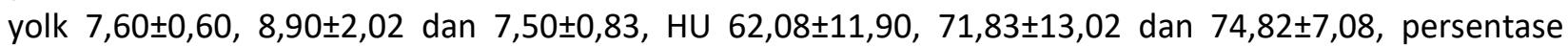
kerabang telur (\%) 12,59,11,35 dan13,09, persentase yolk (\%) 30,60, 35,38, dan 27,64, persentase albumen (\%) 56,81, 53,27dan 59,28. Akseptabilitas telur ayam Ketarras setara telur ayam Kampung sebesar 86,21\%. Dapat disimpulkan, kerabang telur ayam Ketarras berwarna putih kecoklatan seperti kerabang telur ayam Kampung dengan tingkat akseptabilitas setara telur ayam Kampung sebesar 86,21\%. Berat telur, indeks telur, indeks yolk, $\mathrm{HU}$, persentase kerabang telur dan albumen ayam Ketarras lebih tinggi dibanding ayam Arab dan Ayam Kampung. Tebal kerabang telur ayam Ketarras sama dengan telur ayam Arab dengan indek albumen sama dengan telur ayam Kampung. Skor warna dan persentase yolk ayam Ketarras lebih rendah dibanding telur ayam Arab dan ayam Kampung. Kesimpulan penelitian ini adalah warna kerabang telur ayam Ketarras adalah putih kecoklatan seperti telur ayam Kampung dengan tingkat akseptabilitas telur ayam Ketarras setara telur ayam Kampung sebesar $86,21 \%$. Skor warna dan persentase yolk ayam Ketarras lebih rendah dibanding telur ayam Arab dan ayam Kampung.

Kata kunci: ayam Ketarras, ayam Kampung, ayam Arab, kualitas fisik telur, akseptabilitas telur

\section{PENDAHULUAN}

Telur sebagai bahan pangan sumber protein hewani, memiliki rasa lezat, mudah dicerna dan bergizi tinggi, serta dapat dikonsumsi manusia pada segala umur (Soeparno et al., 2011). Saliem et al. (2001) menyatakan, dibanding hasil ternak lain, tingkat konsumsi telur lebih besar, karena telur mudah diperoleh dengan harga yang relatif murah, terjangkau bagi masyarakat yang daya belinya rendah.

Telur ayam merupakan salah satu telur unggas yang banyak dipasarkan.Secara umum telur ayam ada dua macam, yaitu telur ayam Ras dan telur ayam Kampung. Konsumen masih menghargai lebih pada telur ayam Kampung. Terlihat, meskipun ukuran telurnya relatif lebih kecil, namun konsumen bersedia membeli telur tersebut dengan harga lebih tinggi. Sebagian masyarakat berpendapat bahwa telur ini mempunyai khasiat lebih, sehingga digunakan untuk menambah khasiat dalam minum jamu. Sebagian masyarakat juga berpendapat bahwa telur ayam Kampung aman dikonsumsi bagi yang alergi terhadap telur ayam Ras.

Pasokan telur ayam Kampung di pasaran sering tidak mencukupi kebutuhan konsumen. Salah satu penyebabnya adalah relatif rendahnya produktivitas ayam Kampung. Binawati (2008) menyatakan, produktivitas ayam jenis ini berkisar 39 - 135 butir per tahun. Rendahnya produktivitas ini karena ayam jenis ini masih mempunyai aktivitas mengeram (Sulandari, 2007). Kekurangan pasokan tersebut telah terpenuhi oleh telur ayam Arab. Sodak (2011) menyatakan, telur ayam Arab telah banyak beredar di pasaran dengan harga yang sama dengan harga telur ayam Kampung. Hal ini mengindikasikan kedua jenis telur tersebut telah setara. Namun demikian tidak semua konsumen suka pada telur ayam Arab dikarenakan warna kerabangnya putih. Konsumen lebih menyukai warna kerabang yang putih kecoklatan. Berkaitan dengan hal tersebut maka warna kerabang telur ayam Arab perlu dicoklatkan. Upaya ini bisa dilakukan dengan cara menyilangkan ayam Arab dengan ayam yang mempunyai gen warna kerabang telur coklat. Ayam Ketarras adalah ayam persilangan dengan kandungan gen ayam arab $75 \%$ dan ayam Ras 25\%. Menurut Kaharuddin et al. (2020), awal produksi telur ayam Ketarras lebih tinggi dengan konversi ransum lebih baik dibanding ayam Arab, sedangkan 92,65\% warna kerabang telur ayam Ketarras adalah putih kecoklatan. Berdasarkan uraian 
tersebut perlu dilakukan uji daya terima (akseptabilitas) telur ayam Ketarras apakah setara dengan telur ayam Kampung bagi masyarakat. Selain uji akseptabilitas, perlu dievaluasi kualitas fisik telur ayam Ketarras jika dibandingkan dengan telur dari dua jenis ayam lainnya.

Tujuan penelitian ini untuk mengevaluasi kualitas fisik telur ayam Arab, telur ayam Kampung dan telur ayam Ketarras serta akseptabilitas telur ayam Ketarras setara telur ayam Kampung. Diduga akseptabilitas telur ayam Ketarras dan kualitas fisiknya setara dengan telur ayam Kampung.

\section{BAHAN DAN METODE}

Penelitian berlangsung selama satu bulan. Uji kualitas fisik telur dilakukan di Laboratorium Jurusan Peternakan Faperta Universitas Bengkulu. Uji akseptabilitas telur ayam Ketarras setara telur ayam Kampung menggunakan kuisioner dan wawancara langsung kepada konsumen telur ayam Kampung, responden yang berprofesi sebagai penjual jamu dan penjual minuman Bandrek di Jalan Suprapto serta penjual telur di Pasar Minggu, Pasar Kaget dan Pasar Panorama Kota Bengkulu.

\section{Persiapan Telur}

Telur yang digunakan ada 3 jenis, yaitu telur ayam Arab, ayam Kampung dan ayam Ketarras. Telur ayam Arab dan telur ayam Ketarras didapat dari kandang Jurusan Peternakan Fakultas Pertanian Universitas Bengkulu, sedangkan telur ayam Kampung didapat dari peternak di Desa Margo Mulyo Kecamatan Pondok Kubang Kabupaten Bengkulu Tengah.

\section{Pengambilan Data dan Analisis Data}

Uji kualitas fisik telur menggunakan 20 butir telur ayam Arab, 20 butir telur ayam Kampung dan 20 butir telur ayam Ketarras. Uji akseptabilitas telur menggunakan 10 butir pada masing-masing jenis telur yang diletakkan secara acak pada karpet telur (egg tray) dan meminta responden untuk menilainya. Semua data ditabulasi untuk selanjutnya dibahas secara deskriptif.

\section{Variabel Pengamatan}

Variabel kualitas fisik telur bagian luar (eksterior) telur meliputi warna kerabang telur, indeks telur, berat telur, berat kerabang telur dan tebal kerabang telur, sedangkan kualitas fisik telur bagian dalam (interior) meliputi indeks yolk (kuning telur), indeks albumen (putih telur), warna yolk, HU (haugh unit) serta persentase yolk dan albumen telur. Selain data kualitas fisik juga diamati akseptabilitas telur ayam Ketarras setara telur ayam Kampung.

\section{Pengambilan Data Akseptabilitas}

Data akseptabilitas telur ayam Ketarras setara telur ayam Kampung diperoleh dengan menggunakan kuisioner dan wawancara secara langsung kepada responden. Penentuan responden dilakukan secara purposive meliputi konsumen telur ayam Kampung, pedagang (penjual telur), penjual jamu, dan penjual minuman Bandrek. Konsumen telur ayam Kampung sebanyak 6 responden, pedagang telur ayam Kampung di Pasar Panorama 4 responden, di Pasar Minggu 9 responden di Pasar Kaget 4 responden, penjual jamu 3 responden, penjual minuman Bandrek 3 responden, sehingga jumlah responden yang dimintai penilaiannya sebanyak 29 orang responden. Sebanyak 10 butir telur ayam Arab, 10 butir telur ayam Kampung dan 10 butir telur ayam Ketarras diletakkan pada satu karpet telur (egg tray) secara acak dan meminta responden untuk menilai telur tersebut.

\section{HASIL DAN PEMBAHASAN}

\section{Kualitas Fisik Telur Bagian Luar}

Konsumen memilih telur berdasarkan pengamatan telur bagian luar. Kualitas telur bagian luar yang dinilai oleh konsumen meliputi warna, kebersihan dan keretakan telur serta ukuran telur. Kualitas fisik telur 
bagian luar telur dari tiga jenis ayam yang diteliti disajikan pada Tabel 1.

\section{Warna Kerabang Telur}

Rataan skor warna kerabang telur ayam Arab, telur ayam Kampung dan telur ayam Ketarras berturut-turut $1,25 \pm 0,44 ; 1,80 \pm 0,42$ dan 2,10 $\pm 0,31$. Hal ini menunjukkan bahwa warna kerabang telur ayam Ketarras lebih mendekati ayam Kampung dibanding dengan ayam Arab. Faktor yang mempengaruhi warna kerabang telur yaitu genetik (North, 1984). Komposisi genetik Ayam Ketarras adalah 75\% gen ayam Arab dan 25\% gen ayam Ras (Kaharuddin et al., 2020). Diketahui warna kerabang telur ayam Ras petelur adalah coklat, sedangkan pada ayam Arab putih bersih, sehingga kerabang telur yang dihasilkan ayam Ketarras adalah putih kecoklatan menyerupai telur ayam Kampung.

\section{Indeks Telur}

Rataan indeks telur ayam Arab, ayam Kampung dan ayam Ketarras berturut-turut $76,53 \pm 3,03 \%, 74,34 \pm 3,63 \%$ dan $77,63 \pm 6,37 \%$. Terlihat bahwa indeks telur ayam Ketarras $(77,63 \pm 6,37 \%)$ lebih tinggi $1,1 \%$ dibanding ayam Arab (76,53 $\pm 3,03 \%)$ dan lebih tinggi $3,29 \%$ dibanding ayam Kampung (74,34 $\pm 3,63 \%)$. Indeks telur ayam yang normal yaitu 74\% (Soeparno et al., 2011). Menurut Saddat dan Adrizal (2009), indeks telur antara 70 - 79\% adalah baik. Selain itu, telur dengan indeks telur $75 \%$ adalah bulat dan dapat menetas hingga $70-75 \%$, sedangkan telur yang bentuknya lonjong daya tetasnya hanya mencapai 30-35\%. Hal ini menunjukkan bahwa ketiga jenis telur tersebut tergolong normal.

\section{Berat Telur}

Rataan berat telur ayam Arab, ayam Kampung dan ayam Ketarras berturut-turut $39,82 \pm 2,34 \mathrm{~g}, 40,36 \pm 3,48 \mathrm{~g}$ dan 43,29 $\pm 3,18 \mathrm{~g}$. Berat telur ayam Ketarras $(43,29 \pm 3,18 \mathrm{~g})$ lebih tinggi 2,93 g dibanding dengan ayam Kampung $(40,36 \pm 3,48 \mathrm{~g})$ dan lebih tinggi $3,47 \mathrm{~g}$ dibanding ayam Arab $(39,82 \pm 2,34 \mathrm{~g})$. Hal ini menunjukkan bahwa ukuran telur ayam Ketarras relatif lebih besar dibandingkan dengan ukuran telur ayam Arab maupun ayam Kampung. Perbedaan berat telur ini diduga dipengaruhi oleh genetik (dimana ayam Katarras memiliki genetik $75 \%$ ayam Arab dan 25\% ayam Ras), sehingga berat telur ayam Ketarras relatif lebih tinggi dibanding ayam Arab. Menurut Hartono et al. (2014), berat telur dapat dipengaruhi oleh faktor genetik dan pakan.

\section{Tebal Kerabang Telur}

Rataan tebal kerabang telur ayam Arab, ayam Kampung dan ayam Ketarras (Tabel 1.) berturut-turut $0,34 \pm 0,01 \mathrm{~mm}, 0,33 \pm 0,02 \mathrm{~mm}$ dan $0,34 \pm 0,01 \mathrm{~mm}$. Rataan tebal kerabang telur ayam Arab sama dengan ayam Ketarras. Kesamaan ini diduga dikarenakan kedua jenis ayam pada penelitian ini dipelihara dengan sistem pemeliharaan yang sama yaitu secara intensif serta dengan pakan yang sama. Selain itu ayam Ketarras memiliki gen $75 \%$ ayam Arab. Tebal kerabang telur ayam Kampung $(0,33 \pm 0,02 \mathrm{~mm})$ lebih rendah $0,01 \mathrm{~mm}$ dibanding ayam Arab $(0,34 \pm 0,01 \mathrm{~mm})$ dan ayam Ketarras $(0,34 \pm 0,01 \mathrm{~mm})$. Perbedaan ini diduga karena sistem pemeliharaan yang berbeda. Ayam Arab dan ayam Ketarras pada penelitian ini dipelihara dengan sistem intensif pada kandang batteray dengan nutrisi pakan yang cukup, sehingga kebutuhan kalsium pada pembentukan kerabang telur terpenuhi. Sementara ayam Kampung dipelihara dengan sistem pemeliharaan ekstensif (umbaran) sehingga pemenuhan kebutuhan kalsium untuk pembentukan kerabang telur tidak sama dengan ayam Arab dan ayam Ketarras.

Soeparno et al. (2011) menyatakan tebal kerabang telur yang cukup baik adalah minimal 0,33 $\mathrm{mm}$. Tebal kerabang telur ayam Kampung hasil penelitian termasuk normal yaitu 0,33 $\pm 0,02 \mathrm{~mm}$. Tebal kerabang berhubungan dengan berat kerabang telur. Ketebalan kerabang telur merupakan faktor terpenting dalam menentukan kualitas telur, 
Tabel 1. Kualitas fisik telur ayam Arab, telur ayam Kampung dan telur ayam Ketarras bagian luar (eksterior)

\begin{tabular}{lccc}
\hline \multirow{2}{*}{ Variabel } & \multicolumn{3}{c}{ Rataan \pm sd } \\
\cline { 2 - 4 } & Telur ayam Arab & Telur ayam Kampung & Telur ayam Ketarras \\
\hline Warna kerabang telur & $1,25 \pm 0,44$ & $1,80 \pm 0,42$ & $2,10 \pm 0,31$ \\
Indeks telur (\%) & $76,53 \pm 3,03$ & $74,34 \pm 3,63$ & $77,63 \pm 6,37$ \\
Berat telur (g/butir) & $39,82 \pm 2,34$ & $40,36 \pm 3,48$ & $43,29 \pm 3,18$ \\
Tebal kerabang (mm) & $0,34 \pm 0,01$ & $0,33 \pm 0,02$ & $0,34 \pm 0,01$ \\
\hline \multicolumn{1}{c}{ Keterangan: } & Skor warna &
\end{tabular}

Tabel 2. Kualitas fisik telur ayam Arab, telur ayam Kampung dan telur ayam Ketarras bagian dalam (interior)

\begin{tabular}{lccc}
\hline \multirow{2}{*}{ Variabel } & \multicolumn{3}{c}{ Rataan \pm sd } \\
\cline { 2 - 4 } & Telur ayam Arab & Telur ayam Kampung & Telur ayam Ketarras \\
\hline Indeks yolk & $0,44 \pm 0,05$ & $0,40 \pm 0,04$ & $0,46 \pm 0,03$ \\
Indeks albumen & $0,05 \pm 0,02$ & $0,07 \pm 0,03$ & $0,07 \pm 0,02$ \\
Warna yolk & $7,60 \pm 0,60$ & $8,90 \pm 2,02$ & $7,50 \pm 0,83$ \\
Haugh Unit & $62,08 \pm 11,90$ & $71,83 \pm 13,02$ & $74,82 \pm 7,08$ \\
\hline
\end{tabular}

terutama berhubungan dengan proses pengangkutan telur (Hartono et al., 2014).

\section{Kualitas Fisik Telur Bagian Dalam}

Selain kualitas fisik telur bagian luar, kualitas fisik telur bagian dalam seperti warna yolk sangat mempengaruhi tingkat kesukaan konsumen. Konsumen menyukai yolk dengan skor warna berkisar antara 9-11 dalam skor yolk colour fan (Nur, 2015). Kualitas telur ayam bagian dalam (interior) disajikan pada Tabel 2.

\section{Indeks yolk (Kuning Telur)}

Rataan indeks yolk ayam Ketarras $(0,46 \pm 0,03)$ lebih tinggi 0,02 dibanding dengan indeks yolk ayam Arab $(0,44 \pm 0,05)$ dan lebih tinggi 0,06 dibanding dengan indeks yolk ayam Kampung $(0,40 \pm 0,04)$. Diduga genetik mempengaruhi indeks yolk. Ayam Ketarras mempunyai $75 \%$ gen ayam Arab dan $25 \%$ gen ayam Ras petelur coklat. Menurut Yuwanta (2010) genetik mempengaruhi indeks yolk. Selanjutnya dinyatakan indeks yolk segar beragam antara 0,33 dan 0,50 dengan nilai rataan 0,42. Ditambahkan bahwa indeks yolk menurun dengan bertambahnya umur telur, karena penambahan ukuran yolk sebagai akibat pemindahan air. Berdasarkan pernyataan tersebut, rataan indeks yolk ketiga jenis telur yang digunakan tergolong normal.

\section{Indeks Albumen (Putih Telur)}

Rataan indeks albumen telur ayam Arab, ayam Kampung dan ayam Ketarras berturut-

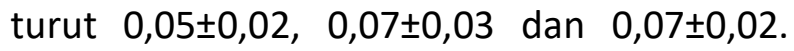
Dengan demikian indeks albumen telur ayam Ketarras sama dengan ayam Kampung dan indeks albumen telur ayam Ketarras lebih tinggi 0,02 dibanding dengan ayam Arab. Yuwanta (2010) menyatakan, kisaran indeks albumen segar adalah 0,050-0,174. Selanjutnya, diameter albumen semakin lebar dengan bertambahnya umur telur, sehingga indeks albumen semakin kecil. Indeks albumen dipengaruhi genetik, tinggi dan diameter albumen serta lama simpan telur. Kualitas albumen menurun dengan lamanya telur disimpan (Hartono et al., 2014). Indeks albumen hasil penelitian berkisar 0,05-0,07 yang tergolong dalam mutu III. SNI (2008) bahwa, albumen dibagi atas tiga golongan yaitu mutu I dengan rataan indeks albumen 0,134-0,175, mutu II dengan rataan indeks albumen 0,092-0,133 dan mutu III rataan indeks albumen 0,050-0,091. 
Warna Yolk (Kuning Telur)

Warna yolk diukur dengan yolk colour fan yang terdiri 15 seri warna; skor terendah yaitu skor 1 berwarna kuning pucat dan skor tertinggi yaitu 15 berwarna orange. Skor warna yolk ayam Kampung $(8,90 \pm 2,02)$ lebih tinggi 1,30 dibanding dengan ayam Arab $(7,60 \pm 0,60)$ dan lebih tinggi 1,40 dibanding dengan ayam Ketarras $(7,50 \pm 0,83)$. Perbedaan ini dipengaruhi oleh genetik dan pakan. Induk ayam Kampung pada penelitian ini dipelihara secara ekstensif (umbaran), sehingga berpeluang mengkonsumsi hijauan sebagai sumber karoten. Sementara, induk ayam Arab dan Ketarras dipelihara secara intensif tanpa diberi hijauan. Menurut Hartono et al. (2014), warna yolk dipengaruhi genetik dan pakan.

Pewarna alami yang mempengaruhi warna yolk adalah xanthophyll yang terdapat dalam hijauan (Nur, 2015). Pigmen yolk dipengaruhi oleh jenis pigmen ransum, seperti jagung bisa menyebabkan warna pekat yolk. Kandungan pigmen yolk termasuk dalam golongan karotenoid yaitu xanthophyll, lutein, zeasantin serta sedikit betakaroten dan kriptosantin (Winarno, 2002). Tingginya skor warna yolk dikarenakan oleh kandungan $\beta$ karotin. Kandungan $\beta$ karotin pakan yang meningkat, maka intensitas warna yolk juga meningkat, dan semakin tinggi kandungan $\beta$ karotin pakan dapat menurunkan kolesterol pada telur (Nuraini et al., 2008).

\section{Haugh Unit (HU)}

Rataan HU telur ayam Arab, ayam Kampung dan ayam Ketarras berturut-turut $62,08 \pm 11,90,71,83 \pm 13,02$ dan 74,82 $\pm 7,08$. Rataan HU menunjukkan bahwa HU pada ayam Ketarras $(74,82 \pm 7,08)$ lebih tinggi 2,99 dibanding ayam Kampung $(71,83 \pm 13,02)$ dan lebih tinggi 12,74 dibanding dengan ayam Arab $(62,08 \pm 11,90)$. Tugiyanti dan Iriyanti (2012) menyatakan, nilai HU dapat dijadikan dasar penilaian kualitas telur. Menurut Sodak (2011), HU antara lain dipengaruhi oleh kekentalan albumen, genetik, lama waktu simpan, suhu serta umur ayam. Satu butir telur terdiri tiga bagian, yaitu kerabang telur, albumen (putih telur), serta yolk (kuning telur). Persentase bagian-bagian telur dari ketiga jenis ayam disajikan pada Tabel 3

Persentase kerabang telur ayam Ketarras (13,09\%) lebih tinggi 0,5\% dibanding dengan ayam Arab (12,59\%) dan lebih tinggi 1,74\% dibanding ayam Kampung (11,35\%). Persentase yolk ayam Kampung (35,38\%) lebih tinggi $4,78 \%$ dibanding ayam Arab (30,60\%) dan lebih tinggi $7,74 \%$ dibanding dengan ayam Ketarras (27,64\%). Persentase albumen ayam Ketarras $(59,28 \%)$ lebih tinggi $2,47 \%$ dibanding dengan ayam Arab $(56,81 \%)$ dan lebih tinggi $6,01 \%$ dibanding ayam Kampung (53,27\%). Dapat dinyatakan bahwa persentase yolk ayam Ketarras relatif lebih rendah dengan persentase albumen serta kerabang telur lebih tinggi dibanding telur ayam Arab dan ayam Kampung. Menurut Soeparno et al. (2011) persentase bagian albumen berkisar 61-65\%, yolk 27-32\% dan kerabang telur 811\%. Menurut Yuwanta (2010), proporsi bagian telur bervariasi, bergantung umur, pakan, suhu, genetik, dan manajemen pemeliharaan.

\section{Akseptabilitas Telur Ayam Ketarras Setara Telur Ayam Kampung}

Pengukuran akseptabilitas dilakukan dengan meminta kepada responden untuk menilai apakah sampel telur yang digunakan pada penelitian termasuk telur ayam Kampung atau bukan. Sebanyak masingmasing 10 butir telur ayam Arab, ayam Kampung dan ayam Ketarras diletakkan secara acak pada karpet telur (egg tray), untuk selanjutnya responden dimintai pendapatnya. Penggunaan sampel telur ayam Arab penelitian dimaksudkan sebagai pembanding karena diketahui bahwa saat ini sebagian masyarakat telah menganggap telur ayam Arab setara dengan telur ayam Kampung. Tabel 4. memperlihatkan hasil penilaian responden. 
Tabel 3.Persentase bagian-bagian telur ayam Arab, telur ayam Kampung dan telur ayam Ketarras

\begin{tabular}{lccc}
\hline \multirow{2}{*}{ Variabel } & \multicolumn{3}{c}{ Persentase bagian-bagian telur (\%) } \\
\cline { 2 - 4 } & Telur ayam Arab & Telur ayam Kampung & Telur ayam Ketarras \\
\hline Kerabang telur & 12,59 & 11,35 & 13,09 \\
Yolk & 30,60 & 35,38 & 27,64 \\
Albumen & 56,81 & 53,27 & 59,28 \\
\hline Total & 100,00 & 100,00 & 100,00 \\
\hline
\end{tabular}

Tabel 4. Hasil penilaian responden terhadap sampel telur yang digunakan

\begin{tabular}{lcc}
\hline & \multicolumn{2}{c}{ Jumlah responden } \\
\cline { 2 - 3 } Responden yang menyatakan semua sampel telur adalah TAK & orang & 17,24 \\
\hline Konsumen TAK & 5 & 6,90 \\
Penjual Jamu & 2 & 10,34 \\
Penjual Bandrek & 3 & 3,45 \\
Penjual TAK di Pasar Kaget & 1 & 20,69 \\
Penjual TAK di Pasar Minggu & 6 & 13,79 \\
Penjual TAK di Pasar Panorama & 4 & 72,41 \\
Jumlah responden menyatakan semua sampel telur adalah TAK & 21 & \\
\hline
\end{tabular}

Responden yang menyatakan tidak semua sampel telur adalah TAK

\begin{tabular}{lcc}
\hline Konsumen TAK & 1 & 3,45 \\
Penjual Jamu & 1 & 3,45 \\
Penjual Bandrek & 0 & 0,00 \\
Penjual TAK di Pasar Kaget & 3 & 10,34 \\
Penjual TAK di Pasar Minggu & 3 & 10,34 \\
Jumlah responden menyatakan tidak semua sampel telur adalah TAK & 8 & 27,59 \\
\hline Total responden & 29 & 100,00 \\
\hline
\end{tabular}

Hasil penilaian responden menunjukkan bahwa dari 29 orang responden, sebanyak 21 $(72,41 \%)$ responden menyatakan bahwa semua telur yang dijadikan sample adalah telur ayam Kampung, sedangkan 27,59\% (8 orang) responden lainnya menyatakan bahwa tidak semua telur yang dijadikan sample termasuk telur ayam Kampung ( Tabel 5.).

Berdasarkan Tabel 6 diketahui bahwa dari 8 responden $(27,59 \%)$, dalam menilai telur yang dijadikan sampel berbeda-beda. Pendapat responden bahwa tidak semua sampel termasuk telur ayam Kampung, karena responden beranggapan bahwa telur ayam dengan warna kerabang putih kecoklatan adalah telur ayam kampung asli sedangkan telur ayam yang warna kerabang putih adalah telur ayam yang dijual di pasaran (telur ayam
Arab) sehingga responden lebih memilih telur ayam dengan warna kerabang putih kecoklatan. Dari 8 responden $(27,59 \%)$ yang menilai telur ayam Ketarras setara telur ayam Kampung adalah 4 responden (13,79\%). Akseptabilitas telur ayam Ketarras setara telur ayam Kampung yaitu 86,21\% (25 responden) dari 29 responden.

Berdasarkan hasil kuisioner, perbedaan antara telur ayam Kampung dengan Telur ayam Arab menurut responden yaitu: 1). Warna yolk ayam Kampung lebih cerah dibanding dengan warna yolk ayam Arab, 2).Tekstur cangkang telur ayam Kampung lebih halus dibanding telur ayam Arab, 3).Warna cangkang telur ayam Kampung ada dua yaitu warna putih kecoklatan dari induk ayam berbulu hitam dan warna putih (bukan 
warna putih cerah) dari induk ayam berwarna bulu putih, coklat, merah dan lain-lain sedangkan warna cangkang telur ayam Arab putih cerah, 4). Berdasarkan ukuran telurnya, telur ayam Kampung relatif lebih kecil dibanding telur ayam Arab, karena menurut responden bahwa ukuran telur dipengaruhi oleh keturunan, fase produksi (awal dan akhir produksi ukuran telur kecil), ukuran induk ayam (jika ayam besar, maka ukuran telurnya besar dan jika induk kecil maka telurnya kecil) dan pakan (jika induk ayam mendapatkan pakan yang bagus maka ukuran telur akan besar dan jika induk ayam mendapatkan pakan yang jelek maka ukuran telur akan kecil).

Tabel 5. Hasil penilaian responden yang menyatakan sampel telur yang digunakan tidak semuanya telur ayam Kampung

\begin{tabular}{|c|c|c|c|c|}
\hline Responden & $\begin{array}{l}\text { Jumlah } \\
\text { responden } \\
\text { (orang) }\end{array}$ & $\begin{array}{l}\text { Jumlah telur } \\
\text { ayam Arab } \\
\text { (butir) }\end{array}$ & $\begin{array}{l}\text { Jumlah telur } \\
\text { ayam } \\
\text { Kampung } \\
\text { (butir) }\end{array}$ & $\begin{array}{l}\text { Jumlah telur } \\
\text { ayam } \\
\text { Ketarras } \\
\text { (butir) }\end{array}$ \\
\hline Konsumen TAK & 1 & 3 & 0 & 6 \\
\hline Penjual Jamu & 1 & 4 & 1 & 5 \\
\hline \multirow{3}{*}{ Penjual TAK di Pasar Kaget } & 1 & 2 & 0 & 5 \\
\hline & 1 & 1 & 0 & 4 \\
\hline & 1 & 4 & 2 & 4 \\
\hline \multirow{3}{*}{ Penjual TAK di Pasar Minggu } & 1 & 2 & 0 & 4 \\
\hline & 1 & 8 & 8 & 6 \\
\hline & 1 & 9 & 10 & 9 \\
\hline Total & 8 & 33 & 21 & 43 \\
\hline $\begin{array}{l}\text { Asumsi jumlah responden yang } \\
\text { menyatakan TAKet adalah TAK yaitu : } \\
10 \text { butir telur terpilih }=1 \text { orang }\end{array}$ & & 3 & 2 & 4 \\
\hline $\begin{array}{l}\text { persentase responden yang menilai } \\
\text { sampel telur adalah TAK }=\text { (jumlah } \\
\text { responden yang menilai sampel telur } \\
\text { adalah TAK/total responden ( } 29 \text { orang) } x \\
100 \% \text { ) }\end{array}$ & & 10,345 & 6,90 & 13,79 \\
\hline $\begin{array}{l}\text { persentase responden yang menilai TAKet } \\
\text { adalah TAK }=(21 \text { orang }+4 \text { orang/total } \\
\text { responden ( } 29 \text { orang) } \times 100 \%)\end{array}$ & & & & 86,21 \\
\hline
\end{tabular}

\section{KESIMPULAN}

Kesimpulan penelitian ini adalah warna kerabang telur ayam Ketarras adalah putih kecoklatan seperti telur ayam Kampung dengan tingkat akseptabilitas telur ayam Ketarras setara telur ayam Kampung sebesar $86,21 \%$. Berat telur, indeks telur, indeks yolk, $\mathrm{HU}$, persentase kerabang telur dan albumen ayam Ketarras lebih tinggi dibanding ayam Arab dan Ayam Kampung. Tebal kerabang telur ayam Ketarras sama dengan ayam Arab dengan indek albumen sama dengan ayam
Kampung. Skor warna dan persentase yolk ayam Ketarras lebih rendah dibanding telur ayam Arab dan ayam Kampung.

\section{DAFTAR PUSTAKA}

Anonimus. 2008. SNI 39262008 Telur Ayam Konsumsi. Badan Standarisasi Nasional. Jakarta.

Binawati, D. K. 2008. Pengaruh laserpunktur terhadap kualitas telur ayam kampung. J. Sci. 2 (1): 28-34. 
Hartono, T. A., A. W. Puger dan I. M. Nuriyasa. 2014. Kualitas telur lima jenis ayam kampung yang memiliki warna bulu berbeda. Jurnal Peternakan Tropika. 2 (2) : 153-162.

Kaharuddin, D., Kususiyah dan M. A. Saputra. 2020. Performa fase awal produksi pada Ayam Ketarras dan Ayam Arab. Buletin Peternakan Tropis. 1(1) : 25-34.

North, 1984. Commercial Chicken Production Manual. 3th ed. The AVI. Publishing Company. Inc. West Port. Connecticut.

Nuraini, Sabrina dan S. A. Latif. 2008. Performa ayam dan kualitas telur yang menggunakan ransum mengandung onggok fermentasi dengan Neurospora crassa. Media Peternakan 31 (3) : 195-201.

Nur, A. 2015. Kualitas telur ayam ras yang dipelihara pada sistem free-range dengan waktu pemberian naungan alami yang berbeda. Skripsi. Fakultas Peternakan Universitas Hasanuddin Makasar.

Saddat, N. dan Adrizal. 2009. Pengaruh pemberian level protein-energi ransum yang berbeda terhadap kualitas telur ayam buras. Seminar Nasional Teknologi Peternakan dan Veteriner, hal. 613-618.

Saliem, H. P., E. M. Lakolo, T. B. Purwantini, M. Ariani dan Y. Marisa. 2001. Analisis ketahanan pangan tingkat rumah tangga dan regional. Laporan hasil penelitian.
Pusat Penelitian dan Pengembangan Sosial Ekonomi Pertanian.Bogor.

Sodak, J. F. 2011. Karakteristik fisik dan kimia telur ayam Arabpada dua peternakan di Kabupaten Tulung Agung, Jawa Timur. Skripsi. Institut Pertanian Bogor, Bogor.

Soeparno, R., A. Rihastuti, Indratiningsih dan S. Triatmojo. 2011. Dasar Teknologi Hasil Ternak. Fakultas Peternakan Universitas Gadjah Mada University Press P.O. Box 14, Bulaksumur, Yogyakarta.

Sulandari, S., M. S. A. Zein, S. Paryanti, T. Sartika, M. Astuti, T. Widjastuti, E. Sudjana, S. Darana, I.Setiawan dan D. Garnida. 2007.Sumberdaya genetik ayam lokal Indonesia. Keanekaragaman sumberdaya hayati ayam lokal Indonesia: manfaat dan potensi. Pusat Penelitian Biologi Lembaga Ilmu Pengetahuan Indonesia, Jakarta. Hal : 45-67.

Tugiyanti, E. dan N. Iriyanti. 2012. Kualitas eksternal telur ayam petelur yang mendapat ransum dengan penambahan tepung ikan fermentasi menggunakan isolat produser antihistamin. Jurnal Aplikasi Teknologi Pakan. 1(2) : 44-47.

Winarno, F.G. dan S. Koswara. 2002. Telur: Komposisi, Penanganan dan Pengolahannya, M-Brio Press, Bogor.

Yuwanta, T. 2010. Dasar Ternak Unggas. Kanisius, Yogyakarta. 